\title{
The Influence Of Realistic Mathematics Education (RME) Approach On Students' Mathematical Communication Ability
}

\author{
$1^{\text {st Reri Seprina Anggraini }}$ \\ Mathematics Department \\ Universitas Negeri Padang \\ Padang, Indonesia \\ rery.anggraini9@gmail.com
}

\author{
$2^{\text {nd }}$ Ahmad Fuzan \\ Mathematics Department \\ Universitas Negeri Padang \\ Padang, Indonesia \\ ahmad.zan66@gmail.com
}

\begin{abstract}
Mathematical communication ability are one of the learning goals, but in reality, student's communication ability are still weak. This research aims compare mathematical communication ability between the students who taught using RME approach and who were taught using conventional approach according to their self-efficacy. Quasi experimental research was conducted at SMP Negeri 5 Kerinci, involving eighth grade students. Data were collected through questionnaires and tests. The results showed that students' mathematical communication ability was higher when they are taught using RME approach than taught using conventional approach both to students who have high self-efficacy and vice versa.
\end{abstract}

Keywords-communication ability, conventional approach, self-efficacy, realistic mathematics education.

\section{INTRODUCTION}

Mathematical communication ability is one of important aspect that should be developed and owned by students in learning mathematics. National Council of Teacher of Mathematics (NCTM) states that the basic mathematical skills that students must possess include problem-solving abilities, reasoning and verification, communication, connections, and representation [3]. The purpose of mathematics learning in the 2013 curriculum also states that one of the goals of learning mathematics is to develop mathematical communication ability. It is important for students to have communication ability as it will assist them in providing explanations and reasons for their answers. National Council of Teacher of Mathematics (NCTM) states that communication is an important part of mathematics and mathematics education. Without good communication, the development of mathematics will be hampered. Communication became central to teaching, judging, and learning mathematics [6].

Using concrete means and sharing student's work with each other, they can develop their oral communication ability and mathematical representations to explain their understanding of mathematical ideas and strategies [1]. According to Pourdavood \& Wachira's opinion which state that it is important for students to have mathematical communication ability, because it will help them to provide explanations and reasons for their answers [2]. However, in fact, mathematical communication ability of junior high school students is still low [4]. Math learning is mostly done using the "chalk and talk" method [5]. As a result, students have difficulty communicating their ideas clearly to friends or teachers through spoken or written language, which makes it more difficult for students to solve problems. To overcome the problem of the low mathematical communication ability of students can be overcome by applying the realistic mathematics education approach (RME).

The RME approach initiated by Freudental is one of the student-oriented learning approaches by starting learning using contextual problems [8]. In line with the results of the research Ekowati et al (2015) which indicates that with a realistic approach to mathematics teachers, can change the habit of teachers considered speakers or informants become facilitators and mediators active and creative in the improvement of student learning activities [7].

RME approach is the opposite of conventional approach. If conventional approach starts with the teacher explaining algorithms or formulas, then RME approach starts with contextual problems. In conventional approach after being given a formula, the teacher gives them examples and practice questions that are similar to examples $[9,10]$.

Conventional approach only provides results to students lead them not be able to try solve contextual problems using their informal knowledge. In RME approach, students have the opportunity to use their knowledge to solve the problem informally in their own way, called horizontal mathematization. Then, through the experience of similar processes (through simplification and formalization), they will use more formal means or symbols that will lead them to rediscover a formal mathematical algorithm or a concept called mathematization vertical [11,10]. Gravemeijer (1994) describes the two mathematization processes as shown in Figure $1[9,13]$.

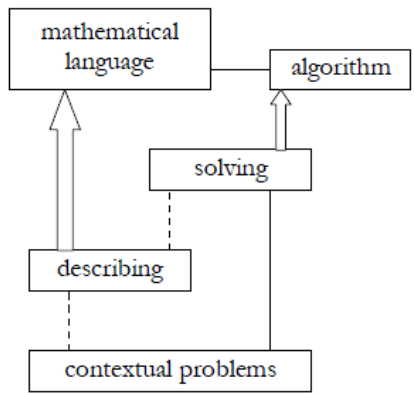

Fig 1. Horizontal Mathematization (----); Vertical Mathematization $\Rightarrow$ ) 
The implementation of horizontal and vertical mathematization indirectly gives students the opportunity to declare mathematical models (images, algebraic expressions) in simple language, explain ideas, situations and mathematical relationships both orally and in writing, and state the mathematical situation or the daily events in the mathematical model and solve it until they finally get the form of an algorithm or a formal formula.

This research also focuses on the level of self-efficacy of students. Self-efficacy is the belief that students must be successful in the learning process. Self-efficacy must be taken into account in determining the learning approach used, because self-efficacy influence mathematical communication ability. A higher level of self-confidence leads to higher mathematical math skills [12].

RME approach oriented contextual issues, provides an opportunity for students to solve problems based on their knowledge, it gives freedom of learners in putting out ideas without being tied to a specific algorithm [12]. Be able to provide ideas needed for the self-efficacy of each student. Thus, in this study an investigation was made whether RME approach would be appropriate for students with different self- efficacy and academic abilities. Self-efficacy is divided into two levels: students who have high self-efficacy and students who have low self-efficacy.

The research questions in this study are as follows: 1) Is the mathematical communication ability of students learning using RME approach are better than those who were learning using conventional approach? 2) Is the mathematical communication ability of students with high self-efficacy learning using RME approach better than those learning using conventional approach? 3) Is the mathematical communication ability of students with low self-efficacy learning using RME approach are better than that of students using conventional approach?

\section{METHOD}

This study is a quasi-experimental research aimed at comparing the influence of RME approach with conventional approach of the mathematical communication ability of students. The variables used in this study are mathematical communication ability as dependent variables, RME approach as independent variables and self-efficacy as the moderator variable.

This research was conducted in SMP Negeri 5 Kerinci. This school was chosen intentionally because it is a school that implement 2013 curriculum in class VIII. To determine the sample class, two classes of class VIII are randomly selected, one class as an experimental class and the other class as a control class. In total, there were 36 students in this research. Students in the experimental class learn using RME approach while students in the control class learn using conventional approach.

The data used in this study are data collected through questionnaires and tests. Questionnaires are used to identify the level of self-efficacy that students have, while tests are used to measure students' mathematical communication ability. The test used was validated by three mathematics lectures, then the test was tested in the other class VIII which has the same characteristics as the sample class to know the validity and the reliability of the test. The communication ability indicators used in the tests are as follows: 1) declare mathematical models (images, algebraic expressions) in simple language; 2) explain mathematical ideas, situations and relationships both orally and in writing; 3) state the mathematical situation or the daily events in the mathematical model and solve it. The data were analyzed using Mann Whitney $\mathrm{U}$ and t-test after testing for normality and homogeneity.

\section{RESULT AND DISCUSSION}

After analyzing the data, we know that students' communication ability is ranked according to the approach applied during learning and the level of self-efficacy of students, can be seen in Table I and Table II.

TABle I. The Average Score of Students' Mathematical COMMUNICATION ABILITY

\begin{tabular}{|l|c|c|}
\hline \multicolumn{1}{|c|}{ Sample Class } & $\overline{\boldsymbol{x}}$ & $\boldsymbol{s}$ \\
\hline Experiment & 6.59 & 1.84 \\
\hline Control & 3.74 & 2.58 \\
\hline
\end{tabular}

Table I shows that the average scores of students who learn using RME approach are higher than those who learn using conventional approach. The standard deviation of the value of the experimental class is lower than control class, indicating that the values of the experiment class are more uniform because they have almost the same ability.

TABELII. The Average Score of Students' Mathematical COMMUNICATION ABILITY ACCORDING ON SELF-EFFICACY LEVEL

\begin{tabular}{|l|l|c|c|}
\hline Self-Efficacy & \multicolumn{1}{|c|}{ Sample Class } & $\overline{\boldsymbol{x}}$ & $\boldsymbol{S}$ \\
\hline \multirow{2}{*}{ High } & Experiment & 6.81 & 1.78 \\
\cline { 2 - 4 } & Control & 4.67 & 2.50 \\
\hline \multirow{2}{*}{ Low } & Experiment & 6.17 & 2.04 \\
\cline { 2 - 4 } & Control & 2.90 & 2.47 \\
\hline
\end{tabular}

Table II shows that the average scores of both high and low self-efficacy students using RME approach have a higher mean score than those studied using conventional approach. Overall it can be concluded that students who have high self-efficacy have the highest average score compared to others.

To know the test used in hypothesis test, firstly tested normality and homogeneity. The test is assisted by SPSS software, the test results can be seen in Table III and Table IV.

TABLEIII. THE RESULTS OF NORMALITY TEST

\begin{tabular}{|l|c|}
\hline \multicolumn{1}{|c|}{ Sample Class } & Sig. \\
\hline Experiment & 0.200 \\
\hline Control & 0.053 \\
\hline
\end{tabular}

TABle IV. The Results of Normality Test AcCording on SelfEFFICACY LEVEL

\begin{tabular}{|l|l|c|}
\hline \multicolumn{1}{|c|}{ Self-Efficacy } & \multicolumn{1}{|c|}{ Sample Class } & Sig. \\
\hline \multirow{2}{*}{ High } & Experiment & 0.200 \\
\cline { 2 - 3 } & Control & 0.054 \\
\hline \multirow{2}{*}{ Low } & Experiment & 0.200 \\
\cline { 2 - 3 } & Control & 0.022 \\
\hline
\end{tabular}

Table III shows that both classes of samples have Sig. > 0.05 , so it can be concluded that the value of the sample classes are normally distributed. Table IV shows that sample classes with students with high self-efficacy are normally distributed because the Sig. > 0.05. While students with low self-efficacy are not normally distributed. 
In addition, homogeneity test for both classes of samples that were studied with a different approach and in the sample class where students had high self-efficacy using SPSS software obtained Sig value in the order is 0.301 and 0.299 . So, the hypothesis test used in the sample class using t-test and sample class with students who have high selfefficacy using two-way ANOVA while class with students who have low self-efficacy using Mann Whitney U test. The results of the hypothesis tests performed using the SPSS software can be found in Tables V and VI.

TABle V. The Results of Hypothesis Testing of Students' MATHEMATICAL COMMUNICATION ABILITY

\begin{tabular}{|c|c|}
\hline Ability & Sig. \\
\hline Mathematical Communication & 0.001 \\
\hline
\end{tabular}

The result of the hypothesis test in Table V shows that the value of Sig. $<0.05$. It can therefore be declared rejected $\mathrm{H}_{0}$, the mathematical communication ability of students who learn using RME approach is better than those who learn using the conventional approach.

TABLE VI.The Results of Hypothesis Testing BASED ON SElFEFFICACY LEVEL

\begin{tabular}{|c|c|}
\hline Self-Efficacy & Sig. \\
\hline High & 0.037 \\
\hline Low & 0.011 \\
\hline
\end{tabular}

The result of the hypothesis test in Table VI shows both Sig. $<0.05$. Thus, it can therefore be declared rejected $\mathrm{H}_{0}$, that is, the students' mathematical communication ability of students with high and low self-efficacy who learn using RME approach is higher than that of learners using the conventional approach.

\section{CONCLUSIONS}

Based on the results of the study can be concluded that students' mathematical communication ability who learn using RME approach are better than those who learn by using conventional approaches. The same is true for students with either high self-efficacy or low self-efficacy. It can therefore be concluded that RME approach contributes to improving students' mathematical communication ability.

\section{REFERENCES}

[1] Yang, E. F. Y., Chang, B., Cheng, H. N. H., \& Chan, T. W. (2016). Improving Pupils' Mathematical Communication Abilities Through Computer-Supported Reciprocal Peer Tutoring. Educational Technology \& Society, 19 (3), 157-169.

[2] Pourdavood, Roland G., \& Wachira, Patrick. 2015. Importance of Mathematical Communication and Discourse in Secondary Classrooms. Global Journal of ScienceFrontier Research: $F$ Mathematics and Decision Sciences, Vol. 15 Issue 1.0. ISSN: 22494626 PP: 9-20.

[3] NCTM. Principles and Standards for School Mathematics. NCTM: USA, 2000.

[4] Surya, Edi., \& Rahayu, Riska. 2014. Peningkatan Kemampuan Komunikasi dan Pemecahan Masalah Matematis Siswa SMP ArRahman Percut melalui Pembelajaran Kooperatif Tipe Student Teams Achievement Division (STAD). Jurnal Pendidikan Matematika PARADIKMA, Vol. 7 Nomor 1, Hal. 24-34.

[5] A. Fauzan, et al. 2013. The Development of RME-based Geometry Course for Indonesian Primary Schools. In An Introduction to Educational Design Research. T. Plomp, T., N. Nieveen N. (Eds). The Netherlands: SLO.

[6] Tiffany, Febry et al. 2017. Analysis Mathematical Communication Skills Strudent at The Grade IX Junior High School. Vo-3 Issue-2. IJARIIE-ISSN(O)-2395-4396. www.ijariie.com .

[7] Ekowati, Ardi, Darwis, Upa, Tahmir, \& Dirawan. 2015. The Application of Realistic Mathematics Education Approach in Teaching Mathematics in Penfui Kupang.International Journal of Education and Information Studies. ISSN 2277-3169 Vol. , No. 1, pp. $35-43$.

[8] H. Freudenthal, Revisiting mathematics education. Dordrecht, The Netherlands: Kluwer Academic, 1991.

[9] A. Fauzan. 2002. Applying Realistic Mathematics Education (RME) in Teaching Geometry in Indonesian Primary Schools. Enschede, The Netherlands: PrintPartners Ipskamp.

[10] A. Fauzan, E. Musdi, R.P. Yani. 2018. The Influence of Realistic Mathematics Education(RME) Approach on Students' Mathematical Representation Ability. Advances in Social Science, Education and Humanities Research, volume 173. 1st International Conference on Education Innovation (ICEI 2017)

[11] A. Treffers, Three dimensions. A model of Goal and Theory Description in Mathematics Education, Dordrecht, The Netherlands: Reidel, 1987.

[12] Rahmi, S., Nadia, R., Hasibah, B., \& Hidayat, W. (2017). The Relation between Self-Efficacy toward Math with the Math Communication Competence. Infinity, 6 (2), 177-182. doi:10.22460/infinity.v6i2.p177-182

[13] Gravemeijer, K. 1994. Developing Realistic Mathematics Education. Utrecht: Freudenthal Institute. 